\title{
PERBANDINGAN NILAI LAJU ENDAP DARAH (LED) ANTARA METODE WESTERGREN DENGAN METODE MIKRO ESR PADA PENDERITA TUBERKULOSIS PARU
}

\author{
Silvia Hidriyah ${ }^{1}$, Mellysa Rahmita ${ }^{1}$, Citra Trisna ${ }^{1}$ \\ ${ }^{1}$ Jurusan Analis Kesehatan, Politeknik Kesehatan Kementerian Kesehatan Banten \\ silviahidriyah@gmail.com
}

\begin{abstract}
One of the diseases that evoke an inflammatory reaction and affect the value of ESR is Pulmonary Tuberculosis. ESR examination suggested by ICSH is Westergren method. But there are many instances where the patient's venous blood sampling is so difficult that the blood obtained is small. One of the modification methods that can be used for ESR examination is the Micro ESR method. The purpose of this research is to know the comparison of ESR values using Westergren and Micro ESR methods. The material used for this research is $3.8 \%$ citrate blood derived from 30 samples of patients with Pulmonary Tuberculosis at Krakatau Medika Hospital Cilegon. The average result of ESR Pulmonary Tuberculosis with Westergren method was 41,83 $\mathrm{mm} / \mathrm{hr}$ and the mean value of ESR Pulmonary Tuberculosis with Micro ESR method was 33,03 mm/hr. The result of this research is processed by statistical test using Paired Sample T Test and got significance value (sig. 2-tailed) $=0,016$. This value is smaller than the value of $\alpha=0.05$ which means there is a difference between the two examination variables, so the Micro ESR method could not be used for patients with Pulmonary Tuberculosis.
\end{abstract}

Keywords : Erythrocyte Sedimentation Rate (ESR), Westergren method, Micro ESR method, Pulmonary Tuberculosis

PENDAHULUAN

Laju Endap Darah (LED) adalah pemeriksaan untuk menentukan kecepatan eritrosit mengendap dalam darah yang berisi berisi antikoagulan pada suatu tabung vertikal dalam waktu tertentu. LED pada umumnya digunakan untuk mendeteksi dan 
memantau adanya kerusakan jaringan, inflamasi dan menunjukan adanya penyakit. ${ }^{7}$

Menurut Thomas (1997) Inflamasi merupakan mekanisme tubuh untuk mempertahankan diri dari benda asing yang masuk, misalnya invasi mikroorganisme, trauma, bahan kimia, faktor fisik dan alergi. Salah satu penyebab inflamasi adalah adanya infeksi bakteri Mycobacterium tuberculosis yang menyebabkan penyakit Tuberkulosis Paru. Tuberkulosis Paru menyebabkan bertambahnya jumlah leukosit berkaitan dengan fungsinya sebagai pertahanan akibat pelepasan protein fase akut ke dalam sirkulasi sehingga menyebabkan peningkatan viskositas plasma serta peningkatan fibrinogen yang dapat mengakibatkan eritrosit mudah rouleaux. ${ }^{9}$

Menurut WHO pada tahun 2016 angka kejadian Tuberkulosis Paru di seluruh dunia sebesar 10,4 juta orang. Indonesia merupakan negara ke-2 terbanyak pasien yang menderita Tuberkulosis Paru setelah India. $^{10}$
Salah satu pemeriksaan untuk menegakkan diagnosis penyakit Tuberkulosis yaitu dengan pemeriksaan darah berupa pemeriksaan hitung jumlah Leukosit dan LED. Metode Westergren adalah metode yang dianjurkan oleh International Commitee for Standardization in Hematology (ICSH) karena hasil LED dalam kondisi normal memiliki nilai yang berbeda dibandingkan metode Wintrobe yang tidak berbeda banyak. $^{7}$

Dalam pemeriksaan LED metode Westergren membutuhkan sampel darah sebanyak 1,6 ml, hal ini dikarenakan volume darah di dalam tabung Westergren harus mencapai batas angka $0 \mathrm{~mm}$ yang berada pada bagian atas tabung. Padahal kenyataannya banyak kejadian dimana pengambilan sampel darah vena pasien sangat sulit, karena faktor-faktor seperti vena tidak adekuat, obesitas, dan kelenturan fleksi. Selain itu, pada neonatus dan anak-anak kecil sangat sulit mengumpulkan 1,6 $\mathrm{ml}$ darah dalam semprit, karena vena neonatus dan bayi kecil sangat tipis dan 
sebagian besar waktu darah keluar berhenti karena perpindahan jarum. ${ }^{1}$ Hal ini membuat beberapa peneliti melakukan penelitian modifikasi pemeriksaan LED menggunakan metode Mikro ESR dengan hanya menggunakan sampel darah sebanyak $\pm 70 \mu \mathrm{l}$ atau $\pm 0,07 \mathrm{ml}^{2}$

Menurut penelitian yang dilakukan oleh Adhikari et al, (2017) menunjukkan bahwa terdapat hubungan yang signifikan antara pengukuran LED metode Westergren dengan Mikro ESR menggunakan sampel darah vena pada pasien normal sehingga metode Mikro ESR dapat digunakan sebagai metode modifikasi dari pemeriksaan LED metode Westergren dengan sampel darah vena pasien normal. Tetapi pada penderita Tuberkulosis Paru, peningkatan sejumlah fibrinogen akan membuat pembentukan rouleaux eritrosit lebih cepat sehingga menyebabkan nilai LED meningkat. ${ }^{1} \quad$ Sedangkan teori menurut ICSH (2011) menyatakan bahwa penggunaan diameter tabung yang lebih sempit akan membuat nilai LED diperlambat. ${ }^{3}$
Berdasarkan latar belakang di atas peneliti bermaksud mengadakan penelitian mengenai LED dengan tujuan mengetahui apakah terdapat perbedaan yang signifikan antara hasil pemeriksaan LED menggunakan metode Westergren dengan metode Mikro ESR pada penderita Tuberkulosis Paru.

\section{METODE PENELITIAN}

Penelitian ini bersifat Deskriptif Analitik dengan membandingkan nilai LED antara metode Westergren dengan metode Mikro ESR pada penderita Tuberkulosis Paru. Penelitian dilakukan di Laboratorium Hematologi Rumah Sakit Krakatau Medika Cilegon. Penelitian mulai dilaksanakan dari bulan Februari 2018 sampai bulan Mei 2018.

Populasi pada penelitian ini adalah pasien yang merupakan penderita Tuberkulosis Paru di Rumah Sakit Krakatau Medika Cilegon selama waktu penelitian. Sampel yang digunakan dalam penelitian ini sebanyak 30 orang pasien penderita Tuberkulosis Paru di Rumah Sakit Krakatau Medika 
Cilegon selama waktu penelitian secara acak.

Data yang dikumpulkan berupa data primer dari pencatatan hasil pemeriksaan LED setiap sampel, antara nilai LED metode Westergren dengan nilai LED metode Mikro ESR pada penderita Tuberkulosis Paru.

Darah diambil pada vena pasien menggunakan spuit sebanyak $3 \mathrm{ml}$ sesuai SOP pengambilan darah vena, setelah itu darah dimasukkan ke dalam tabung berisi antikoagualan $\mathrm{K}_{3}$ EDTA dan dihomogenkan. Darah sitrat $3,8 \%$ kemudian dibuat dengan pencampuran 4 bagian darah EDTA dengan 1 bagian Natrium Sitrat 3,8\% dalam tabung reaksi kecil.

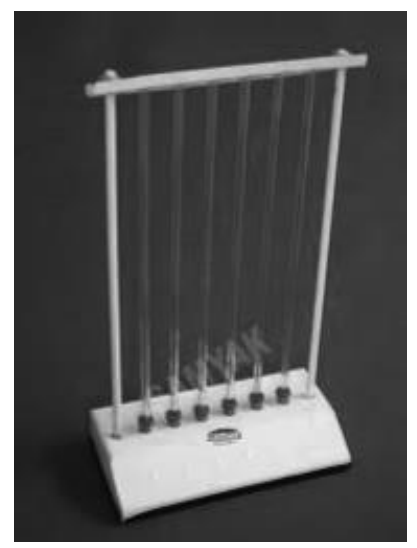

\section{Rak serta Tabung Westergreen ${ }^{8}$}

Dalam metode Westergren, darah sitrat 3,8\% dihisap ke dalam tabung Westergren dengan bantuan bulb. Darah dihisap sampai tanda batas 0 yang terdapat di bagian atas tabung. Tabung kemudian ditempatkan pada rak tabung Westergren dengan posisi tegak lurus pada tempat rata dan jauh dari getaran dalam suhu ruangan. Setelah 60 menit, tinggi plasma diukur dalam satuan mm dari tanda batas 0 sampai tanda batas eritrosit mengendap. Tingginya plasma yang terbentuk dilaporkan sebagai nilai LED dalam satuan $\mathrm{mm} / \mathrm{jam}$.

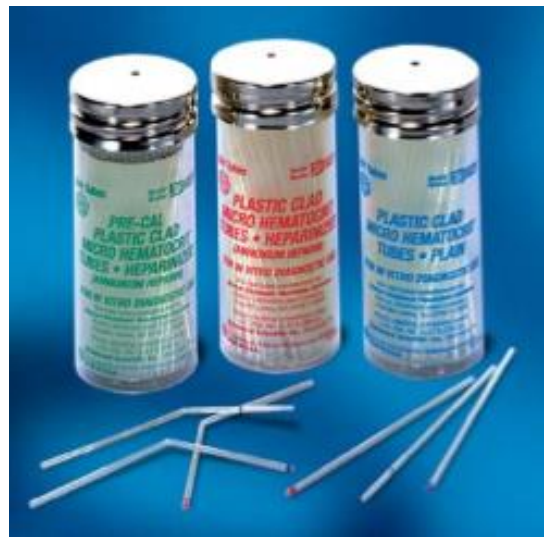

Tabung Kapiler Hematokrit ${ }^{5}$

Untuk pemeriksaan metode Mikro ESR, pertama darah sitrat $3,8 \%$ dihisap ke dalam tabung kapiler non-hematokrit oleh daya kapilaritas tabung. Tabung diisi darah sampai $3 / 4$ bagian tabung kapiler terisi penuh. Bagian ujung tabung yang berisi darah kemudian 
Silvia Hidriyah,dkk. Perbandingan Nilai Laju Endap Darah.

disumbat dengan plasticine dan device dalam satuan mm dimulai dari ditempatkan pada posisi tegak lurus di Plasticine Base Capillary Holder. Selama proses berlangsung, tabung dijauhkan dari getaran dalam suhu ruangan. Setelah 60 menit, tinggi tanda batas atas bagian plasma sampai tanda batas eritrosit mengendap. Tingginya plasma yang terbentuk dilaporkan sebagai nilai LED dalam satuan $\mathrm{mm} / \mathrm{jam}$. plasma diukur menggunakan reading

\section{HASIL PENELITIAN}

Tabel 1. Hasil Pemeriksaan Laju Endap Darah dengan Metode Westergren dan Mikro ESR Pada Penderita Tuberkulosis Paru

\begin{tabular}{clcc}
\hline \multirow{2}{*}{ No. } & \multirow{2}{*}{ Nama Pasien } & \multicolumn{2}{c}{ Nilai Laju Endap Darah (mm/jam) } \\
\cline { 3 - 4 } & & Metode Westergren & Metode Mikro ESR \\
\hline 1 & A & 78 & 52 \\
\hline 3 & Y & 16 & 43 \\
\hline 4 & R & 23 & 27 \\
\hline 5 & H.S & 66 & 64 \\
\hline 6 & I & 33 & 25 \\
\hline 7 & F & 50 & 37 \\
\hline 8 & T.H & 29 & 23 \\
\hline 9 & T.A & 27 & 17 \\
\hline 10 & H & 41 & 43 \\
\hline 11 & P & 63 & 42 \\
\hline 12 & B.K & 29 & 24 \\
\hline 13 & M.A & 21 & 19 \\
\hline 14 & M & 25 & 28 \\
\hline 15 & D.Y & 66 & 47 \\
\hline 16 & W & 28 & 26 \\
\hline 17 & N.A & 72 & 47 \\
\hline 18 & L & 2 & 1 \\
\hline 19 & S & 51 & 39 \\
\hline 20 & R.M & 6 & 59 \\
\hline 21 & D.I & 79 & 59 \\
\hline 22 & S & 40 & 30 \\
\hline & & 107 & \\
\hline
\end{tabular}




\section{Lanjutan Tabel 1}

\begin{tabular}{llcc}
\hline \multirow{2}{*}{ No. } & \multirow{2}{*}{ Nama Pasien } & \multicolumn{2}{c}{ Nilai Laju Endap Darah (mm/jam) } \\
\cline { 3 - 4 } & & Metode Westergren & Metode Mikro ESR \\
\hline 23 & S.M & 41 & 38 \\
\hline 24 & M.Y & 74 & 45 \\
\hline 25 & E.S & 11 & 20 \\
\hline 26 & Y & 12 & 19 \\
\hline 27 & M & 146 & 76 \\
\hline 28 & A & 7 & 12 \\
\hline 29 & E.Y.S & 2 & 6 \\
\hline 30 & N & 10 & 23
\end{tabular}

Pada tabel 1 menunjukkan bahwa nilai terendah pemeriksaan LED penderita Tuberkulosis Paru metode Westergren adalah sebesar 2 $\mathrm{mm} / \mathrm{jam}$ dan nilai tertinggi sebesar $146 \mathrm{~mm} / \mathrm{jam}$. Sedangkan nilai terendah untuk pemeriksaan LED penderita Tuberkulosis Paru metode Mikro ESR adalah sebesar $1 \mathrm{~mm} / \mathrm{jam}$ dan nilai tertinggi sebesar 76 $\mathrm{mm} / \mathrm{jam}$.

Berdasarkan tabel 1 data yang diperoleh, didapatkan nilai LED yang normal dari metode Westergren sebanyak 7 orang $(23,3 \%)$ dengan jenis kelamin laki-laki 4 orang $(57,1 \%)$ dan perempuan 3 orang (48,9\%), sedangkan nilai LED yang meningkat sebanyak 23 orang (76,7\%) dengan jenis kelamin laki- laki 11 orang $(47,8 \%)$ dan perempuan 13 orang $(52,2 \%)$.

Pada metode Mikro ESR didapatkan nilai LED yang normal sebanyak 7 orang $(23,3 \%)$ dengan dengan jenis kelamin laki-laki 3 orang $(48,9 \%)$ dan perempuan 4 orang $(57,1 \%)$, sedangkan nilai LED yang meningkat sebanyak 23 orang $(76,7 \%)$ dengan jenis kelamin lakilaki 13 orang $(52,2 \%)$ dan perempuan 11 orang $(48,9 \%)$.

Data yang telah diperoleh kemudian diolah dengan Uji Paired Sample T Test untuk mengetahui ada tidaknya perbedaan hasil pemeriksaan LED antara metode Westergren dengan Mikro ESR pada penderita Tuberkulosis Paru. Ada tidaknya perbedaan dapat dilihat pada tabel 2 dan tabel 3 : 
Tabel 2. Data Statistik Hasil Pemeriksaan Laju Endap Darah dengan Metode Westergren dan Mikro ESR Pada Penderita Tuberkulosis Paru

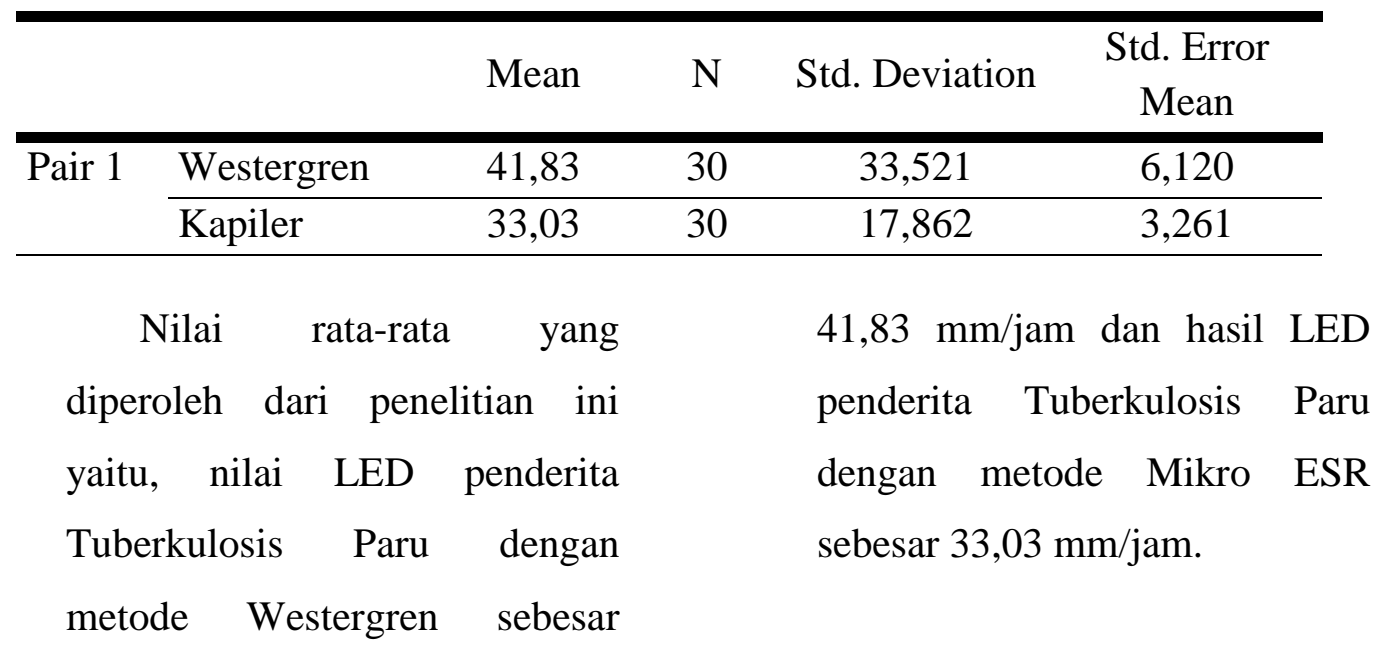

Tabel 3. Uji Paired Sample T Test

\begin{tabular}{|c|c|c|c|c|c|c|c|c|c|}
\hline & & \multicolumn{5}{|c|}{ Paired Differences } & \multirow{3}{*}{$\mathrm{t}$} & \multirow{3}{*}{ df } & \\
\hline & & \multirow[t]{2}{*}{ Mean } & \multirow[t]{2}{*}{$\begin{array}{c}\text { Std. } \\
\text { Deviation }\end{array}$} & \multirow[t]{2}{*}{$\begin{array}{l}\text { Std. Error } \\
\text { Mean }\end{array}$} & \multicolumn{2}{|c|}{$\begin{array}{c}95 \% \text { Confidence } \\
\text { Interval of the } \\
\text { Difference }\end{array}$} & & & $\begin{array}{l}\text { Sig. } \\
(2- \\
\text { tailed })\end{array}$ \\
\hline & & & & & Lower & Upper & & & \\
\hline $\begin{array}{l}\text { Pair } \\
1\end{array}$ & $\begin{array}{l}\text { Westergren - } \\
\text { Kapiler }\end{array}$ & 8,800 & 18,858 & 3,443 & 1,758 & 15,842 & 2,556 & 29 & ,016 \\
\hline
\end{tabular}

Pada tabel 3 dapat diketahui ada atau tidaknya perbedaan antara kedua variasi yang dilakukan oleh peneliti terhadap pemeriksaan Laju Endap Darah pada penderita Tuberkulosis Paru. Perbedaan ini diketahui dengan melihat Nilai Probabilitas atau Sig. (2-tailed) di kolom terakhir yaitu sebesar 0,016. Nilai ini lebih kecil dari $\alpha(0,05)$ yang artinya terdapat perbedaan dari kedua variabel pemeriksaan, sehingga merupakan bukti kuat untuk menolak $\mathrm{H}_{0}$.

\section{PEMBAHASAN}

Subyek pada penelitian ini berjumlah 30 pasien, pada metode Westergren didapatkan nilai LED yang normal sebanyak 7 orang $(23,3 \%)$ dengan jenis kelamin lakilaki 4 orang $(57,1 \%)$ dan perempuan 3 orang $(48,9 \%)$, sedangkan nilai LED yang lebih dari normal 
sebanyak 23 orang $(76,7 \%)$ dengan jenis kelamin laki-laki 11 orang $(47,8 \%)$ dan perempuan 13 orang $(52,2 \%)$.

Pada metode Mikro ESR didapatkan nilai LED yang normal sebanyak 7 orang $(23,3 \%)$ dengan dengan jenis kelamin laki-laki 3 orang $(48,9 \%)$ dan perempuan 4 orang $(57,1 \%)$, sedangkan nilai LED yang lebih dari normal sebanyak 23 orang $(76,7 \%)$ dengan jenis kelamin laki-laki 13 orang $(52,2 \%)$ dan perempuan 11 orang $(48,9 \%)$.

Penetapan hasil untuk nilai LED normal adalah 0 hingga $20 \mathrm{~mm} / \mathrm{jam}$ untuk perempuan dan 0 hingga 15 $\mathrm{mm} / \mathrm{jam}$ untuk laki-laki, jika nilai LED lebih dari nilai normal maka LED dinyatakan meningkat. ${ }^{7}$

Peningkatan nilai LED pada penderita Tuberkulosis Paru sesuai dengan teori dari Thomas (1997) dimana dikatakan bahwa Mycobacterium tuberculosis yang menginfeksi alveolus akan membangkitkan reaksi peradangan (inflamasi). Reaksi ini akan menyebabkan peningkatan viskositas plasma serta peningkatan fibrinogen. Sedikit peningkatan dari kadar fibrinogen dalam darah dapat memberikan peningkatan yang besar pada LED. ${ }^{9}$ Hal ini disebabkan karena fibrinogen dapat menurunkan muatan negatif eritrosit (potensial zeta). Potensial zeta berperan untuk menjaga eritrosit saling menjauh. Jika potensial zeta menurun, maka eritrosit akan membentuk formasi rouleaux (tersusun seperti koin bertumpuk) yang dapat mengendap lebih cepat. $^{6}$ Sementara nilai LED yang normal disebabkan karena penderita sudah melakukan pengobatan dan berada dalam tahap penyembuhan penyakit.

Berdasarkan penelitian yang dilakukan dalam mengukur nilai Laju Endap Darah dengan Metode Westergren dan Mikro ESR pada penderita Tuberkulosis Paru terhadap 30 sampel, menunjukkan adanya perbedaan yang signifikan antara kedua variabel pemeriksaan. Pada pemeriksaan Laju Endap Darah metode Westergren nilai yang didapatkan lebih besar daripada metode Mikro ESR pada penderita Tuberkulosis Paru di Rumah Sakit Krakatau Medika Cilegon. 
Menurut penelitian yang telah dilakukan oleh Adhikari et al,. pada tahun 2017, nilai LED yang diperiksa dengan metode Westergren dan Mikro ESR ${ }^{1}$ menunjukkan korelasi yang baik. Pada penelitian lain yang dilakukan oleh Maria dan Alberto pada tahun 2009, menyatakan bahwa nilai LED antara metode Wintrobe dengan metode Mikro ESR juga memiliki korelasi yang baik, dengan nilai $\mathrm{r}=0,76(\mathrm{P}<0,001){ }^{4}$ Berdasarkan uraian hasil kedua penelitian tersebut, terdapat perbedaan hasil yang tidak sejalan dengan penelitian ini. Perbedaan ini disebabkan karena sampel yang digunakan untuk kedua penelitian tersebut berasal dari populasi pasien dengan kondisi normal, sedangkan sampel yang digunakan untuk penelitian ini berasal dari populasi pasien dengan kondisi abnormal yang menyebabkan reaksi inflamasi.

Perbedaan nilai LED yang signifikan ini kemungkinan disebabkan karena pada pemeriksaan LED metode Mikro ESR pipet yang digunakan lebih pendek dan memiliki diameter yang lebih sempit dibandingkan dengan pipet yang digunakan untuk metode Westergren. Penggunaan pipet kapiler pada metode Mikro ESR membuat pengendapan eritrosit berlangsung lebih lama karena adanya peningkatan kadar fibrinogen akibat reaksi inflamasi oleh Mycobacterium tuberculosis. Fibrinogen adalah salah satu jenis protein plasma yang merupakan protein terbesar yang ada di dalam plasma darah.

Pada pemeriksaan LED metode Mikro ESR ketika proses pengendapan eritrosit berlangsung, adanya kadar fibrinogen yang tinggi dalam plasma yang berukuran makro akan menghambat eritrosit untuk mengendap karena sempitnya ruang pipet kapiler yang digunakan. Sehingga membuat nilai LED diperlambat.

Berdasarkan hasil penelitian yang dilakukan didapatkan sebanyak 21 orang penderita Tuberkulosis Paru mengalami peningkatan nilai LED yang lebih besar pada metode Westergren, sedangkan 9 orang lainnya (30\%) mengalami peningkatan nilai LED yang lebih besar pada metode Mikro ESR. Perbedaan peningkatan nilai LED 
dari dua metode ini disebabkan karena Laju Endap Darah (LED) banyak dipengaruhi oleh berbagai faktor diantaranya yaitu faktor sel darah merah, komponen plasma, dan faktor teknis.

\section{SIMPULAN}

Berdasarkan hasil penelitian terhadap 30 sampel dapat dinyatakan bahwa pemeriksaan Laju Endap Darah (LED) metode Mikro ESR tidak dapat digunakan untuk pasien penderita Tuberkulosis Paru karena setelah dilakukan penelitian terdapat perbedaan nilai LED yang bermakna antara metode Westergreen dengan Mikro ESR.

\section{UCAPAN TERIMA KASIH}

Kepada direktur rumah sakit krakatau medika yang telah memberikan izin penelitian.

\section{DAFTAR RUJUKAN}

1. Adhikari BC, Patra S, Chanda C, dan Shrivastava RK. 2017. Erythrocyte sedimentation rate, measurement by capillary tube method, (micro esr)- best method for neonate and small children. Journal of Medical Science and Clinical Research. 5(5):2213522137.
2. Douglas SE dan Randolph TR. 2007. Development of a micro-esr system with potential for in-home use. Clinical Laboratory Science. 20(1).

3. ICSH, International Council For Standardization In Haematology. 2011. ICSH review of the measurement of the erythocyte sedimentation rate. International Journal of Laboratory Hematology. 33:125-132.

4. Maria dan Alberto. 2009. Determinación de la velocidad de sedimentación globular mediante micrométodo comparado con el método Wintrobe. ENF INF MICROBIOL. 29(2):66-69.

5. McCall RE dan Tankersley CM. 2012. Phlebotomy Essentials. 5th $E d$. Wolters Kluwer. China.

6. McPherson RA, Pincus MR. 2011. Hematology, Coagulation, and Transfusion Medicine. 22nd Ed. Elsevier Saunders. Philadelphia.

7. Nugraha, G. 2015. Panduan Pemeriksaan Laboratorium Hematologi Dasar. Cetakan Pertama. Trans Info Media. Jakarta.

8. Raphael, S.S. 1996. Lynch's Medical Laboratory Technology. 3rd Ed. W.B.Saunders Company. London.

9. Tahumuri A, Wongkar MCP, Rotty LWA. 2017. Gambaran laju endap darah dan c-reactive protein pada pasien tuberkulosis paru di Manado 2016. Jurnal Kedokteran Klinik. 1(3):16-20.

10. WHO, World Health Organization. 2017. Tuberculosis. From, http://www.who.int/mediacentre/f actsheets/fs104/en/. 04 Desember 2017 (12:59). 